\title{
Development of Masterplan and Initial Program for Food Security in Papua Region, Indonesia
}

\section{Ambar Pertiwiningrum ${ }^{1}$}

Fakultas Peternakan, Universitas Gadjah Mada

Yogyakarta, Indonesia

\section{Cahyono Agus}

Fakultas Kehutanan, Universitas Gadjah Mada

Yogyakarta, Indonesia

\section{Supriadi}

Kementerian Desa, Pembangunan Daerah Tertinggal dan Transmigrasi

Jakarta, Indonesia

\section{Supriyanta}

Kementerian Desa, Pembangunan Daerah Tertinggal dan Transmigrasi

Jakarta, Indonesia

\section{Ali Agus}

Fakultas Peternakan, Universitas Gadjah Mada

Yogyakarta, Indonesia

\section{Richard P. Napitupulu}

Fakultas Kehutanan, Universitas Jambi

Jambi, Indonesia

\section{Yudistira Soeherman}

Fakultas Peternakan, Universitas Gadjah Mada

Yogyakarta, Indonesia

Artikel Masuk : 5 Januari 2018

Artikel Diterima : 11 Juli 2018

Tersedia Online : 31 Agustus 2018

\begin{abstract}
Food Security and Vulnerability Atlas (FSVA) of Indonesia 2015 categorized the vulnerability to food and nutrition insecurity based on nine indicators covering food availability, food access and food utilization. According to the assessment, 14 districts in priority 1 (severely vulnerable to food insecurity) were all in Papua. Responding to the problems of food insecurity, a multi-year program focusing on two regencies, i.e., Manokwari and Merauke, was conducted from August 2015. The program was developed in cooperation with the Ministry of Villages, Disadvantaged Regions and Transmigration (Kemendes PDTT), Gadjah Mada University Yogyakarta and district governments. This research aimed to examine the problems causing
\end{abstract}

\footnotetext{
${ }^{1}$ Korespondensi Penulis: Fakultas Peternakan, Universitas Gadjah Mada, Yogyakarta, Indonesia Email: artiwi@mail.ugm.ac.id
} 
food insecurity and to develop integrative and collaborative macro-scale policy recommendations. The study used a qualitative descriptive method and a pilot project approach to address food insecurity problems in both regencies. It found five main issues related to food insecurity in Papua: the prevalence of stunting among children under five, the ratio of per capita normative consumption towards net cereal production, the population living below poverty line, households without access to clean water, and low-income families. The problems could be overcome by concerning the ratio of normative consumption per capita and the preservation of local food, and local crops should be grown especially tubers. Regarding the problems associated with low-income families, a program that should be implemented is the welfare improvement of the rural low-income families through the optimization of land resources in the integrated and intensive ways in response to many land resources still underutilized. Moreover, water treatment should be encouraged further to tackle clean water issues.

Keywords: community empowerment; food security; masterplan; sustainable natural management; world food program

\section{Introduction}

The realization of national food security begins with the fulfillment of food in the smallest region, namely villages. Therefore, reducing problems in every aspect of food security in the community to the village levels is a challenge that needs continuous monitoring (Hanani, Sujarwo, \& Asmara, 2015). Lantarsih, Widodo, Darwanto, Lestari, \& Paramita (2011) state that the requirement to achieve national food security relates to the availability of adequate quantities of food in compliance with the nutritional needs of the population. Homegrown food production remains the main pillar in the national food supply corresponding to the realization of national food security and sovereignty.

World Health Organization (WHO) defines food security as: "when all people at all times have access to sufficient, safe, nutritious food to maintain a healthy and active life" (UNHCR, 2013). Conversely, the communities with food insecurity consuming insufficient and poor quality food may engage in socially undesirable activities to obtain food. Food insecurity is a major cause of poor nutritional status in the global population (De Vriese, 2006). Severe short- and long-term health implications (Foley et al., 2010) include poor physical, mental and social health (Strauss \& Corbin, 1994). Food insecurity can be chronic and persistent, generally caused by extreme or acute poverty, which is transitory and often triggered by violent conflict or forced migration (Hadley, Zodhiates, \& Sellen, 2007).

According to World Food Summit (1996), the definition of food security is a state where all people, at all times, have physical and economic access to sufficient, safe, and nutritious food in a good quality and accordance with their preferences so they have a quality of life that is healthy and productive. Food insecurity remains a crucial issue (FAO, 2006) and the Government of Indonesia is incapable of eradicating it entirely yet. The food insecurity conditions occur when some people have a protein-energy deficit because they consume less than the recommended daily intake of calories $(2,000 \mathrm{kcal}$ per capita) and protein (52 grams per capita). The analysis of the Central Bureau of Statistics (2006) showed that more than half of the districts/cities in Indonesia contribute the prevalence of malnourished children under five years at 25 percent. Food insecurity rate of Indonesia has worsened it until 2012 and continued to rise in terms of quantity and percentage of the total population. Based on the Basic Health Research (Riset Kesehatan Dasar) done by the Ministry of Health in 2013, referring to cases found nationally, there was a continued increasing number of undernutrition and malnutrition cases among children under five years.

Food problems at the national level relate to economic stability for the population and national security. Food access difficulties can be caused by several factors, such as the number of national food availability, food distribution, food quality and the food price affordability 
for various societal strata. Food security for households means access by all members at all times to adequate food for an active healthy life (Widada, Masyhuri, \& Mulyo, 2017). Omotesho, Adewumi, \& Fadimula (2007) state that food security at the national level does not cover the whole community, especially the poor. The poor have minimum access to nutritional needs due to regional, economic and social inequalities. There is food insecurity in some rural populations because they do not produce enough food and have enough purchasing power to meet their dietary needs.

Papua's food security and vulnerability atlas illustrated the condition of food security and vulnerability of Papua Province in 156 districts with eleven pilot districts as well as the actual states. Thirteen districts belonged to the first priority of food insecurity and most of them were in Jayawijaya Regency. Twenty-five districts were in the second priority of food insecurity, and nine districts among them were in Boven Digoel Regency. Twenty-three districts belonged to the third priority of food insecurity, and most of them were located in Boven Digoel Regency (seven districts). Fifty-three districts were in the fourth priority and forty-two other districts belonged to the fifth priority. No district in Papua was included in the sixth priority (World Food Programme, 2015). Based on the mapping of FSVA of Indonesia 2015 published by Food Security Council and the World Food Programme, 34 percent of children under five years were stunted, three quarters of the districts had a surplus of cereals, poverty in Indonesia had been reduced but still high, and 34 percent of households had no access to clean water (World Food Programme, 2015). Syarief \& Fatchiya (2014) state that empowering vulnerable communities in the border region to participate in agricultural development for supporting food security is the most appropriate option. A direct experience gained by the community in the field is the initial capital to build independence.

Based on the previous research done by World Food Programme (2015), the causes of food insecurity in Papua were dominated by poor infrastructure access and livelihood basic needs fulfillment. The three highest indicators reflecting the food insecurity state were of the limited access to road/water transportation (72.09 percent), life expectancy (69.18 percent) and limited clean water (55.41 percent). These factors determined food distribution and production in Papua, resulting in adverse impacts on other indicators such as the low ratio of cereal consumption to output and high poverty levels. The solution required for this complex and sustainable problems was the integration of food security efforts.

Concerning research by Timmer (2004), the impact of rice price on the poor with the real wage approach carries out multiplier effect assumptions on a broader macroeconomy for the investment in infrastructure development. It aimed to balance the needs between producers and consumers as an approach to food security in Indonesia. The study of Ilaboya, Atikpo, Omofuma, Asekhame, \& Umukoro (2012) revealed several important causes and challenges regarding food insecurity in the global scope and its relationship with economic growth. This research aimed to examine the problems causing the food insecurity and to develop integrative and collaborative macro-scale policy recommendations to solve those problems. This study focused on analyzing the causes and impacts of food insecurity with measures to achieve food security. The method utilized a mathematical model to examine the effect of vulnerability to national trade or macroeconomic sphere. The study also illustrated some of the effort factors that affected significantly to the level of global food insecurity including the increase of agricultural production, capacity, and technology, as well as the facilitation of market access related to the opportunities outside rural agriculture. The research of the United States Academy International Development (2012) examined the monitoring of food insecurity issues in international, regional and national level, and described the implementation accepted globally. The results of the study also explained the achievements of Indonesia's food security information system currently. The monitoring activities will bring up recommendations regarding the further steps that the Indonesian Government should consider in strengthening the monitoring of food security and early warning capacity. However, examining food insecurity indicators at a spatial level to produce 


\section{Development of Masterplan and Initial Program for Food Security in Papua Region, Indonesia}

a plan from sub-level to macro policy is still insufficient to food insecurity eradication. The concrete steps are needed at the policy level so that the program can be implemented effectively. This research features that spirit especially in alleviating food insecurity in Papua.

\section{Methods}

\section{Data Collection}

The primary data collection used three techniques, namely: 1) direct observation of the objects, 2) interviewing targeted respondents by using structured and semi-structured questionnaires, and 3) focus group discussion (FGD) with multiple-stakeholder participants. To collect answers from respondents, they were divided into two groups: the local community and the government agencies. Respondents from the local community were asked for information about (a) community characteristics, including sources of livelihood and income, economic activities, food and economic assets, conditions of the area/village associated with food needs; (b) evaluation of the government food programs, programs that had been accomplished and their sustainability, community participation in the programs, relevance of the programs to the needs of the community, aspiration for future programs to overcome food insecurity. Respondents from the government agencies were asked for data related to the implementation of the government food programs. Meanwhile, a semistructured questionnaire was used to gather data from the community leaders in groups when a structured one from the households.

The secondary data collection used recording techniques to acquire data from the agencies or institutions involved in this research. These included several publications from the National Statistics Center, Regional Planning Agency (Badan Perencanaan dan Pembangunan Daerah/BAPPEDA), and other related agencies. The secondary data was used to complete the available primary data as the main source of analysis.

\section{Data Analysis}

This research design applied qualitative approach and used descriptive analysis method in generating research phenomenon to understand some aspects related to the research topic (Cooper \& Schlinders, 1998). The collected data were analyzed from the perspective of the needs for policy direction and program intervention to make changes from food vulnerability to food security. In doing so, the conditions and typology of the agroecosystem, the existing socio-economic conditions, and the variations of local food resources in each area were also considered during the analysis steps. Quantification of qualitative data was made by scoring of data. Data analysis by Ridjal (2004) was designed with the following steps: 1) data collection; 2) data reduction; 3) data display; 4) verification and affirmation of conclusions.

\section{Result and Discussion}

\section{Food Security Masterplan}

Food Security Masterplan (Rencana Induk Ketahanan Pangan) was a planning document prepared to provide a policy direction and guidance for programs in handling vulnerable areas to food insecurity in the next five years (2015-2019). The preparation of the masterplan documents in Papua was conducted in two regencies: Manokwari and Merauke. Figure 1 shows a summarized process of preparing the regional Food Security Masterplan in Papua. 


\section{FOOD SECURITY MASTER PLAN}

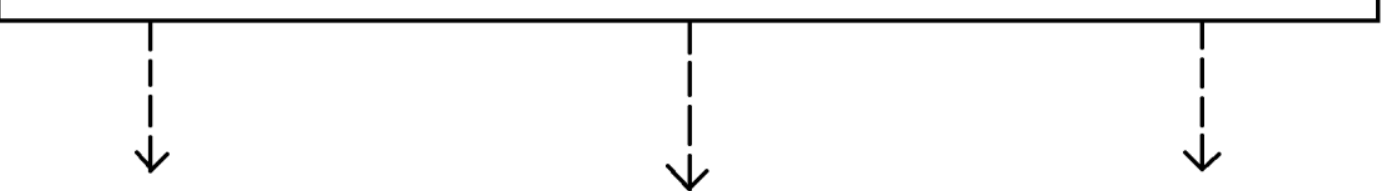

\section{Basic policy \\ direction and \\ framework at district level}

\author{
Basic policy direction \\ and framework of the \\ utilization of local \\ leading commodity at \\ district level
}

\author{
On site designing: \\ from vulnerable \\ area into food \\ security area
}

Source: Authors Analysis, 2017

Figure 1. The Outputs of Food Security Masterplan

\section{The Characteristics of the Regions}

The local farm production has determined food security and food self-sufficiency at the household level. Some areas with the limited support of natural resources considered as the marginal area. Thus, many households lived in the marginal area will face food insecurity (Mulyo, Sugiyarto, \& Widada, 2015). Based on the food expenditure share level, most of the households fell into secure food household category. The food self-sufficiency, mainly in rice consumption, has been attained. Measured as the ratio of calorie availability to domestic demand, food security at the national level has improved and seemed to be stable over time (Saliem, Mardiyanto, \& Simatupang, 2003).

The humanity in the worldwide level is facing severed nutritional imbalances depending on access to food and the dietary habit of a particular population that can make them suspected of malnutrition (Abbade \& Dewes, 2014). Food insecurity status of the area studied, based on FSVA 2015, is showed in Table 1.

Table 1. Food Insecurity Status of Study Area Based on FSVA 2015

\begin{tabular}{|c|c|c|c|c|c|c|c|}
\hline \multirow[b]{2}{*}{ District } & & \multicolumn{5}{|c|}{ Cases } & \multirow{2}{*}{$\begin{array}{c}\text { Key Issues of } \\
\text { Food Insecurity } \\
\text { in the District } \\
\text { Based on FSVA }\end{array}$} \\
\hline & & $\mathrm{P} 1$ & P2 & P3 & $\mathrm{P} 4$ & P5 & \\
\hline \multirow{2}{*}{ Manokwari } & 2009 & $10-<20 \%$ & $>1,5$ & $>35 \%$ & $>30 \%$ & $40-50 \%$ & \multirow{2}{*}{ P1, P2, P5 } \\
\hline & 2015 & $>40 \%$ & $>1.5$ & $<10 \%$ & $30-40 \%$ & $25-35 \%$ & \\
\hline \multirow{2}{*}{ Merauke } & 2009 & $20-<20 \%$ & $0,5-0,75$ & $2,5-<3,5 \%$ & $25-<30 \%$ & $40-50 \%$ & \multirow{2}{*}{$\mathrm{P} 1, \mathrm{P} 3, \mathrm{P} 4$} \\
\hline & 2015 & $>40 \%$ & $<0.5$ & $25-30 \%$ & $50-60 \%$ & $10-15 \%$ & \\
\hline
\end{tabular}

P1: The prevalence of stunting among children under five years

P2: Ratio of per capita normative consumption towards net cereal production

P3: Population living below the poverty line

P4: Households without access to clean water

P5: Low-income families

Source: World Food Programme, 2015 


\section{Development of Masterplan and Initial Program for Food Security in Papua Region, Indonesia}

Manokwari Regency has the highest rainfall in February reaching $248 \mathrm{~mm} / \mathrm{month}$. The total annual precipitation is relatively high and distributed throughout a year which is good for the continuity of food production to support a secure food area. Nevertheless, Manokwari area is prone to earthquakes and tsunamis due to its location at Sorong and Ransiki fault zone. The prevalence of stunting among children under five was recorded very high in the region. Also, the ratio of consumption to production had a high deficit. The food production was still low due to simple agricultural technology. The regency also faces the challenges with the conversion of agricultural land to oil palm plantation, the risk of flooding and drought. Some superior commodities other than rice are corn, cassava, and sweet potatoes. In addition, there are alternative food sources such as taro, bananas, and coconuts. Agriculture, plantation, fishery and animal husbandry are still managed in a traditional way, so their productivities are very low that leads to a deficit in food production and consumption of rice (9,016 tons per year). Cattle were raised traditionally instead of being managed in captivity due to the lack of funding to build the gated enclosures in contrast to the abundant green fields available to feed freely. The constraints in the development of cattle population were the traditional breeding management and the low awareness of people in animal feeding utilization.

Merauke Regency has 23 percent of lowland dry forests. Natural disasters such as erosion and flooding have become the obstacles to food crop production. The uneven population distribution poses some difficulties in providing public services and facilities. Human resources issues related to the low level of education and skills have lowered the bargaining position of the local labor force in the job market. These areas require particular attention due to the poor quality of drinking water and water supplies, the (mostly) brackish groundwater and the existing behavior of the most people in the study area (Kimam District) to consume rainwater.

The conditions of food insecurity in Manokwari and Merauke were more dominated by the prevalence of stunting among children under five years that was quite high reaching 30-40 percent. Another obstacle in food production, such as land conversion into oil palm plantations as well as the poor quality of drinking water, has posed a serious concern. The regencies also need to preserve local foods, such as sweet potato varieties, which have been replaced with rice. Noticeably, paddy straws have never been reused as cattle feeding sources; rather, they have been burnt out by the local people. Paddy straw waste actually remains useful to provide free cattle food to sustain the development of intensive cattle breeding.

In general, the Papuans consume sago as a staple food for a source of energy. The sago tree is an endemic plant that can be easily found in the Papua land. The conditions are now very different, including for the people of Manokwari and Merauke. Based on the data from Central Bureau of Statistics (2017a), the average monthly per capita expenditure of the people in Manokwari Regency in fulfilling the energy source need is dominated by rice consumption (7,241 kg per capita per month). It is far higher than the consumption of other staple food such as corn, cassava, sweet potatoes and sago (even not reaching $1 \mathrm{~kg}$ per capita per month). This consumption behavior change is likely to be affected by the central government policy related to rice distribution as part of pro-poor food subsidies. Before rice became the dominant source of energy, rice was a sumptuous food for the Papuans because it was difficult to get at that time. The subsidized rice for the poor can be one of the factors that affect the consumption choice of the Papuans, as shown by the data of subsidized rice distribution in Manokwari Regency. The data showed a fluctuation but tended to increase, i.e., 12,083,985 $\mathrm{kg}$ (2011), 12,525,250 kg (2012), 11,459,813 (2013), 11,671,620 kg (2014) and $15,524,324 \mathrm{~kg}$ (2015). A similar trend also occurred in the Merauke Regency case. Based on the data from Central Bureau of Statistics (2017b), the amount of subsidized rice distribution in Merauke Regency were 13,543,250 kg (2011), 12,083,985 kg (2012), 12,525,250 kg (2013), $11,459,813 \mathrm{~kg}$ (2014), 11,671,620 kg (2015) and 15,005,500 kg (2016). Such an increased 
trend provides reasonable evidence that the Papuans have shifted staple food consumption by choosing rice over other types of energy sources.

\section{Role of Local Government and Institutions in the Community}

Community empowerment is one forms of conflict resolution through self-reliance approach. This concept suggests a conflict resolution by encouraging the community to improve their welfare independently. In this process, institutions act as a facilitator to accompany the empowerment process in the community. This empowerment concept is also in line with the idea of food security where the focus of food security includes the provision of food consumption at the household level (Mustofa, 2012).

The local government attention on the food insecurity issue still needs some improvements. In all districts, food security affairs are the responsibility of the Central Government Task Forces (Satuan Kerja Perangkat Daerah) which has the same level of authority with the local government agencies or offices. The problems of food insecurity are multidimensional and multisectoral matters so that the food affairs require a strong synergy and coordination among several related government agencies. The task force units in a region often have difficulties in coordinating and synchronizing each other. The local government has initiated a program to address the issue of food insecurity, but the integration and continuity still need to be improved. The most important thing and often overlooked is the role and function of the program to decline the level of food insecurity itself. The programs need to be re-assessed related to the main target and achievements (outcomes) expected in the medium and long-term. Many programs are designed and implemented without the basis of baseline data, so it is difficult to measure their level of achievement at a certain time. The masterplan for food security in Papua is presented in Table 2.

Table 2. Masterplan for Food Security in Papua

\begin{tabular}{|c|c|c|c|c|c|}
\hline \multirow[b]{2}{*}{$\begin{array}{c}\text { Focus on } \\
\text { Issues Based } \\
\text { on FSVA }\end{array}$} & \multirow[b]{2}{*}{$\begin{array}{l}\text { Region's } \\
\text { Agro- } \\
\text { ecosystem } \\
\text { Condition }\end{array}$} & \multirow[b]{2}{*}{$\begin{array}{c}\text { Resume of } \\
\text { Socio- } \\
\text { Economic } \\
\text { Conditions }\end{array}$} & \multirow[b]{2}{*}{$\begin{array}{l}\text { Region's } \\
\text { Policy } \\
\text { Direction }\end{array}$} & \multicolumn{2}{|c|}{ Food Security Masterplan } \\
\hline & & & & $\begin{array}{l}\text { The Choice } \\
\text { of Program } \\
\text { Intervention }\end{array}$ & $\begin{array}{c}\text { Supporting } \\
\text { Activities }\end{array}$ \\
\hline $\begin{array}{l}\text { 1. Commu- } \\
\text { nity's low } \\
\text { food } \\
\text { consumption } \\
\text { 2. High } \\
\text { prevalence of } \\
\text { stunting } \\
\text { among } \\
\text { children under } \\
\text { five years } \\
\text { 3. Poor quality } \\
\text { of drinking } \\
\text { water and } \\
\text { clean water for } \\
\text { the community }\end{array}$ & $\begin{array}{l}\text { 1. The main } \\
\text { food } \\
\text { commodities: } \\
\text { The major } \\
\text { food source } \\
\text { for the com- } \\
\text { munity is rice } \\
\text { cultivation on } \\
\text { the fields } \\
\text { 2. The } \\
\text { availability of } \\
\text { land for food } \\
\text { production: } \\
\text { Potential vast } \\
\text { tracts of land, } \\
\text { and part of it } \\
\text { has not been } \\
\text { managed } \\
\text { /utilized }\end{array}$ & $\begin{array}{l}\text { 1. Social } \\
\text { cohesion: } \\
\text { Social life in the } \\
\text { villages } \\
\text { observed is } \\
\text { quite well, there } \\
\text { are no obstacles } \\
\text { related to social } \\
\text { conflicts or } \\
\text { conflicts of } \\
\text { interest } \\
\text { 2. Motivation } \\
\text { and work } \\
\text { ethics of the } \\
\text { community to } \\
\text { progress are } \\
\text { quite well, but } \\
\text { the indepen- } \\
\text { dence still needs } \\
\text { to be improved }\end{array}$ & $\begin{array}{l}\text { 1. To } \\
\text { improve the } \\
\text { quality of } \\
\text { food/nutrition } \\
\text { intake for } \\
\text { children, } \\
\text { mothers, and } \\
\text { lactating } \\
\text { mothers } \\
2 . \text { To } \\
\text { improve the } \\
\text { quality and } \\
\text { quantity of } \\
\text { food produc- } \\
\text { tion facilities } \\
\text { and infra- } \\
\text { structure }\end{array}$ & $\begin{array}{l}\text { To improve } \\
\text { family's } \\
\text { ability in } \\
\text { producing } \\
\text { and proces- } \\
\text { sing nutri- } \\
\text { tious food } \\
\text { based on } \\
\text { local food } \\
\text { resources }\end{array}$ & $\begin{array}{l}\text { 1. To use the } \\
\text { houses' } \\
\text { backyard to } \\
\text { sustain family } \\
\text { nutrition } \\
2 \text {. To increase } \\
\text { the capability } \\
\text { of nutritious } \\
\text { food proces- } \\
\text { sing } \\
\text { 3. The protein } \\
\text { production on a } \\
\text { household scale }\end{array}$ \\
\hline
\end{tabular}




\begin{tabular}{|c|c|c|c|c|c|}
\hline \multirow[b]{2}{*}{$\begin{array}{c}\text { Focus on } \\
\text { Issues Based } \\
\text { on FSVA }\end{array}$} & \multirow[b]{2}{*}{$\begin{array}{l}\text { Region's } \\
\text { Agro- } \\
\text { ecosystem } \\
\text { Condition }\end{array}$} & \multirow[b]{2}{*}{$\begin{array}{l}\text { Resume of } \\
\text { Socio- } \\
\text { Economic } \\
\text { Conditions }\end{array}$} & \multirow[b]{2}{*}{$\begin{array}{l}\text { Region's } \\
\text { Policy } \\
\text { Direction }\end{array}$} & \multicolumn{2}{|c|}{ Food Security Masterplan } \\
\hline & & & & $\begin{array}{l}\text { The Choice } \\
\text { of Program } \\
\text { Intervention }\end{array}$ & $\begin{array}{c}\text { Supporting } \\
\text { Activities }\end{array}$ \\
\hline $\begin{array}{l}\text { 4. Preserva- } \\
\text { tion of local } \\
\text { food varieties }\end{array}$ & $\begin{array}{l}\text { 3. Pasture } \\
\text { and potential } \\
\text { grazing land: } \\
\text { Pasture still } \\
\text { vastly avail- } \\
\text { able, and } \\
\text { grazing } \\
\text { potential is } \\
\text { very high } \\
\text { 4. Water } \\
\text { potential for } \\
\text { cultivation: } \\
\text { the natural } \\
\text { potential of } \\
\text { the river flow } \\
\text { is high } \\
\text { enough, but } \\
\text { not all used } \\
\text { for irrigation } \\
\text { system } \\
\text { 5. Rainfall: } \\
\text { Very high, } \\
\text { around } \\
\text { 2,008.38 mm/ } \\
\text { year } \\
\text { 6. Variation } \\
\text { of food } \\
\text { sources: The } \\
\text { community's } \\
\text { staple food is } \\
\text { rice, with food } \\
\text { sources varia- } \\
\text { tion of corn, } \\
\text { soybeans, } \\
\text { green beans, } \\
\text { groundnuts, } \\
\text { cassava, and } \\
\text { sweet potatoes } \\
\text { Problems: } \\
\text { - Conversion } \\
\text { of forest to oil } \\
\text { palm planta- } \\
\text { tions without } \\
\text { considering } \\
\text { the environ- } \\
\text { mental issue. } \\
\text { Annual flood } \\
\text { damage food } \\
\text { land area }\end{array}$ & $\begin{array}{l}\text { 3. Village } \\
\text { organization } \\
\text { and farmer's } \\
\text { group: Village } \\
\text { government } \\
\text { institutions } \\
\text { function well in } \\
\text { serving the } \\
\text { community. } \\
\text { Farmer's group } \\
\text { has been formed } \\
\text { long and } \\
\text { capable of } \\
\text { functioning } \\
\text { 4. Education: } \\
\text { the lack of } \\
\text { education, skills } \\
\text { and human } \\
\text { resources are } \\
\text { the causes of the } \\
\text { high } \\
\text { unemployment. } \\
\text { Training for } \\
\text { specialized } \\
\text { skills are needed } \\
\text { to improve the } \\
\text { quality of } \\
\text { human } \\
\text { resources } \\
\text { 5. The } \\
\text { technical } \\
\text { ability to } \\
\text { cultivate: } \\
\text { People have } \\
\text { been using the } \\
\text { method of } \\
\text { intensive rice } \\
\text { cultivation. } \\
\text { Livestock is still } \\
\text { cultivated by } \\
\text { traditional } \\
\text { grazing systems. } \\
\text { Intensive broiler } \\
\text { farms have been } \\
\text { cultivated on a } \\
\text { small scale } \\
\text { population } \\
\text { 6. Agricultural } \\
\text { technology: } \\
\text { People are }\end{array}$ & $\begin{array}{l}\text { 3. To develop } \\
\text { and increase } \\
\text { the consump- } \\
\text { tion of local } \\
\text { food varieties } \\
\text { 4. To increase } \\
\text { family access } \\
\text { to sources of } \\
\text { clean water. } \\
\text { 5. To build an } \\
\text { installation of } \\
\text { clean water to } \\
\text { meet the } \\
\text { needs of the } \\
\text { community } \\
6 \text {. To } \\
\text { maintain the } \\
\text { pattern of } \\
\text { local food } \\
\text { consumption } \\
7 . \text { To increase } \\
\text { the produc- } \\
\text { tivity of } \\
\text { paddy fields } \\
8 \text {. To develop } \\
\text { an instituti- } \\
\text { onal system } \\
\text { that can } \\
\text { perform the } \\
\text { functions of } \\
\text { coordination } \\
\text { and synergy } \\
\text { across sectors }\end{array}$ & $\begin{array}{l}\text { The program } \\
\text { to improve } \\
\text { the low- } \\
\text { income } \\
\text { families' } \\
\text { welfare } \\
\text { through the } \\
\text { optimization } \\
\text { of land } \\
\text { resources in } \\
\text { the integrated } \\
\text { and intensive } \\
\text { ways }\end{array}$ & $\begin{array}{l}\text { 1. To establish } \\
\text { the food } \\
\text { security } \\
\text { working group } \\
\text { which is the } \\
\text { collaboration } \\
\text { between local } \\
\text { government } \\
\text { institutions and } \\
\text { the military } \\
\text { 2. To recruit } \\
\text { food security } \\
\text { cadre } \\
\text { 3. To train food } \\
\text { security cadre } \\
\text { 4. To develop } \\
\text { food cultivation } \\
\text { demonstration } \\
\text { plot by food } \\
\text { security cadre }\end{array}$ \\
\hline
\end{tabular}




\begin{tabular}{|c|c|c|c|c|c|}
\hline \multirow[b]{2}{*}{$\begin{array}{c}\text { Focus on } \\
\text { Issues Based } \\
\text { on FSVA }\end{array}$} & \multirow[b]{2}{*}{$\begin{array}{c}\text { Region's } \\
\text { Agro- } \\
\text { ecosystem } \\
\text { Condition }\end{array}$} & \multirow[b]{2}{*}{$\begin{array}{l}\text { Resume of } \\
\text { Socio- } \\
\text { Economic } \\
\text { Conditions }\end{array}$} & \multirow[b]{2}{*}{$\begin{array}{c}\text { Region's } \\
\text { Policy } \\
\text { Direction }\end{array}$} & \multicolumn{2}{|c|}{ Food Security Masterplan } \\
\hline & & & & $\begin{array}{l}\text { The Choice } \\
\text { of Program } \\
\text { Intervention }\end{array}$ & $\begin{array}{c}\text { Supporting } \\
\text { Activities }\end{array}$ \\
\hline & $\begin{array}{l}\text { - The land for } \\
\text { food produc- } \\
\text { tion is limited } \\
\text { to the yard } \\
\text { Risk of } \\
\text { Disaster: } \\
\text { Earthquake } \\
\text { and tsunami, } \\
\text { because it is } \\
\text { located in the } \\
\text { vicinity of the } \\
\text { fault }\end{array}$ & $\begin{array}{l}\text { already quite } \\
\text { familiar with the } \\
\text { use of modern } \\
\text { agricultural } \\
\text { equipment such } \\
\text { as tractors, } \\
\text { manual } \\
\text { threshing and } \\
\text { milling machine } \\
\text { 7. Potential } \\
\text { commodities: } \\
\text { Besides the } \\
\text { staple food, } \\
\text { there are } \\
\text { potential for } \\
\text { rubber, coffee } \\
\text { and oil palm } \\
\text { plantations }\end{array}$ & & & \\
\hline
\end{tabular}

According to Puspaningtyas, Zauhar, \& Mindarti (2016), the implementation of these strategies with different approaches may include: 1) prioritizing business development; 2) prioritizing the development of human resources; and 3) prioritizing the development of societal societies with increased employment. There are four components in the regional economic development strategy: 1) based on local wisdom (locality); 2) business and economic-based; 3) human resources; and 4) community power (institutional). Perceptions and components of the planning strategy should be inline with tand support to he National Development Planning System in Indonesia. Collaborative planning is a planning that relies on stakeholder-oriented communications and involves both the stakeholders and communities (Healey, 2007; Allmendinger and Tewdwr-Jones, 2002; in Sufianti, 2014) 14). According to Wheeler and Beatley (2004 in Lawalata, 2013), the sustainable perspective is supported by three interconnected pillars, i.e., social pillar as basic human needs, environmental pillar covering the ecology and earth resources, and the economic pillar that consists of money and benefits.

According to Thompson (2013 in Civic Voice, 2018), the sustainable development planning will be very useful if the knowledge and commitment of local communities are involved in every stage of the planning process. It enables communities, the private sectors, and local authorities to work together creatively to add the value of the development in all sectors (physical, social, economic and environmental), so it will become sustainable planning. Rauf, Rahmawaty, \& Said (2013) stated that the yards could be optimized for the use of food and board while maintaining and improving ecological conditions to increase and sustain biodiversity. Syarief, Sumardjo, Kriswantriyono, \& Wulandari (2017) stated that the benefits obtained in the application of integrated farming systems (including agroforestry systems) are an increase in outputs that are more varied, namely in the form of food, feed, fiber, wood, fuel, green manure, and cages. Also, economically integrated farming systems have other advantages, namely reducing the risk of crop failure. 


\section{Development of Masterplan and Initial Program for Food Security in Papua Region, Indonesia}

\section{Conclusion}

There were five main issues related to food insecurity in Papua, i.e., the prevalence of stunting among children under five years, the ratio of per capita normative consumption towards net cereal production, the population living below poverty line, households without access to clean water, and low-income families. Insufficient nutritional intake caused the high stunting prevalence on the toddlers themselves and pregnant women. Several factors were associated with the stunting problems, including the lack of energy and protein, chronic disease that often occurs, inadequate feeding practices and poverty. Those problems also need to be responded to enhance the ability of families to consume nutritious food. This aspect of malnutrition can be overcome by the implementation of the Family's Capacity Improvement Program in Producing and Processing Nutritious Food Based on Local Food Resource. This program needs to be supported by a wide range of household-scale productive activities such as backyard farming to produce vegetables for the family, and raising free-range chickens on "mini" scale to produce eggs as a source of supplemental protein for the family. The "mini" scale (5-10 chickens) aims to reduce the burden of breeding costs to zero. The needs of poultry feed in such business volume can be provided by the household's food waste and other sources.

The problems concerning the ratio of per capita normative consumption towards net cereal production and the preservation of local food can be overcome by growing the local crops primarily tubers. Strict monitoring should also be conducted to control the conversion of agricultural land to grow food into oil palm fields. The problems concerning low-income families can be dealt with a program implemented such as the improvement of the welfare of rural low-income families through the optimization of land resources in the integrated and intensive ways. The program is based on the findings that a lot of land resources in the study locations have not been utilized optimally. Regarding clean water issues, the efforts to apply appropriate technology should be encouraged to meet the community's needs for clean water and drinking water.

\section{References}

Abbade, E. B., \& Dewes, H. (2014). Food insecurity worldwide derived from food supply patterns. Food Security, 71), 109-120. doi:10.1007/s12571-014-0405-x.

Central Bureau of Statistics. (2006). Gross domestic product of Semarang Regency. Central Bureau Statistic of Semarang Regency.

Central Bureau of Statistics. (2017a). Manokwari Regency in figures. Retrieved from manokwarikab.bps.go.id. 2017.02.06.

Central Bureau of Statistics. (2017b). Merauke Regency in figures. Retrieved from meraukekab.bps.go.id. 2017.02.06.

Civic Voice. (2018). Collaborative planning for training impact. Retrieved from . www.jtp.co.uk.

Cooper, D. R., \& Schlinders, P. S. (1998). Business research methods (Sixth). Boston: Irwin/McGraw-Hill.

De Vriese, M. (2006). Refugee livelihoods: A review of the evidence. Geneva. Retrieved from http://www.unhcr.org/4423fe5d2.pdf.

Foley, W., Ward, P., Carter, P., Coveney, J., Tsourtos, G., \& Taylor, A. (2010). An ecological analysis of factors associated with food insecurity in South Australia, 2002-7. Public Health Nutrition, 13(2), 215-221. doi:10.1017/S1368980009990747.

Food and Agriculture Organization (FAO). (2006). Food security. Policy Brief. doi:10.1016/j.jneb.2010.12.007.

Hadley, C., Zodhiates, A., \& Sellen, D. W. (2007). Acculturation, economics and food insecurity among refugees resettled in the USA: A case study of West African refugees. Public Health Nutrition, 19(4), 405-412. 
doi:10.1017/S1368980007222943.

Hanani, N., Sujarwo, S., \& Asmara, R. (2015). ( Indicator and Assessment of Village Food Insecurity Level for. AGRISE, $X V(2), 101-109$. Retrieved from http://agrise.ub.ac.id/index.php/agrise/article/view/167/182.

Ilaboya, I. R., Atikpo, E., Omofuma, F. E., Asekhame, F. F., \& Umukoro, L. (2012). Causes, effects and way forward to food insecurity. Iranica Journal of Energy \& Environment, 3(2), 180-188. doi:10.5829/idosi.ijee.2012.03.02.1673.

Lantarsih, R., Widodo, S., Darwanto, D. H., Lestari, S. B., \& Paramita, S. (2011). Ketersediaan pangan nasional: Kontribusi ketersediaan dan konsumsi energi serta optimalisasi distribusi beras. Jurnal Analisis Kebijakan Pertanian, g(1), 33-51. $\quad$ Retrieved from http://ejurnal.litbang.pertanian.go.id/index.php/akp/article/view/4186.

Lawalata, G. M. (2013). Prinsip-prinsip pembangunan jalan berkelanjutan. Transportasi, 13(2), $115-124$. Retrieved from http://journal.unpar.ac.id/index.php/journaltransportasi/article/view/531.

Mulyo, J. H., Sugiyarto, \& Widada, A. W. (2015). Ketahanan dan kemandirian pangan rumah tangga tani daerah marginal di Kabupaten Bojonegoro. Agro Ekonomi, 26(2), 121-128.

Mustofa. (2012). Analisis ketahanan pangan rumah tangga miskin dan modal sosial di provinsi DIY. Jurnal Geomedia, 19(1), 1-5.

Omotesho, O. A., Adewumi, M. O., \& Fadimula, K. S. (2007). Food security and poverty of the rural households in Kwara State, Nigeria. In $A A A E$ Conference Proceedings (pp. 571-575). Ghana.

Puspaningtyas, A., Zauhar, S., \& Mindarti, L. I. (2016). Analysis of regional economic development planning based on local economic potential development and regional competitiveness improvement. International Journal of Business and Management Invention, 5(8), 1-5. Retrieved from http://www.ijbmi.org/papers/Vol(5)8/version-2/A05820105.pdf.

Rauf, A., Rahmawaty, \& Said, D. B. T. . (2013). Sistem pertanian terpadu di lahan pekarangan mendukung ketahanan pangan berkelanjutan dan berwawasan lingkungan. Jurnal Online Pertanian Tropik, 1(1), 9-20. Retrieved from https://jurnal.usu.ac.id/tropik/article/view/4661.

Ridjal, T. (2004). Metode bricolage dalam penelitian sosial. In B. Burhan (Ed.), Metode Penelitian Kualitatif, Aktualisasi Metodologis ke Arah Ragam Varian Kontemporer (First Edit). Jakarta: PT. Raja Grafindo Persada.

Saliem, H. ., Mardiyanto, S., \& Simatupang, P. (2003). Perkembangan dan prospek kemandirian pangan nasional. Analisis Kebijakan Pertanian, I(2), 123-142.

Strauss, A., \& Corbin, J. (1994). Grounded theory methodology-An overview. In K. . Norman \& S. L. . Vannaeds (Eds.), Handbook of Qualitative Research (pp. 22-23). Thousand Oaks: Sage Publications.

Sufianti, E. (2014). Kepemimpinan dan Perencanaan Kolaboratif pada Masyarakat Non-Kolaboratif. Jurnal Perencanaan Wilayah Dan Kota, 25(1), 78-96. doi:10.5614/jpwk.2014.25.1.5.

Syarief, R., \& Fatchiya, A. (2014). Kajian model pemberdayaan ketahanan pangan di Wilayah Perbatasan antar Negara. Jurnal Ilmu Pertanian Indonesia, 19(1), 9-13.

Syarief, R., Sumardjo, Kriswantriyono, A., \& Wulandari, Y. P. (2017). Pengembangan ketahanan pangan melalui pemberdayaan masyarakat di kawasan rawan konflik Timika Papua. Jurnal Ilmu Pertanian Indonesia, 22(3), 163-171. doi:10.18343/jipi.22.3.163.

Timmer, C. P. (2004). Food security in Indonesia: Current challenges and the long-run outlook (Working Paper Number 48 November 2004).

United Nations High Commissioner for Refugees (UNHCR). (2013). UNHCR global appeal 2014-2015 - Ecuador. Geneva.

United States Academy International Development. (2012). Food security monitoring and early warning systems international, regional and national examples, and Indonesia's application of best practices. United States: Nathan Associates Inc. 


\section{Development of Masterplan and Initial Program for Food Security in Papua Region, Indonesia}

Widada, A. W., Masyhuri, \& Mulyo, J. H. (2017). Determinant factors of food security in Indonesia. Agro Ekonomi, 28(2), 205-219.

World Food Programme. (2015). Food security and vulnerability atlas of Indonesia 2015.

World Food Summit. (1996). Rome declaration on World Food Security. 